\title{
Primary hypoparathyroidism in a patient with common variable immunodeficiency associated enteropathy
}

\author{
RASHAD ISMAYILOV ${ }^{1}$, ILGIN YILDIRIM SIMSIR ${ }^{2}$, DENIZ AKYOL ${ }^{3}$, FATMA OMUR ARDENIZ $^{4}$ \\ ${ }^{1}$ Ege University Faculty of Medicine, Izmir, Turkey \\ ${ }^{2}$ Ege University Faculty of Medicine, Department of Endocrinology and Metabolism Disorders, \\ Izmir, Turkey \\ ${ }^{3}$ Ege University Faculty of Medicine, Department of Infectious Diseases and Clinical Microbiology, \\ Izmir, Turkey \\ ${ }^{4}$ Ege University Faculty of Medicine, Department of Immunology and Allergy Diseases, \\ Izmir, Turkey
}

\begin{abstract}
Background. Common variable immunodeficiency (CVID) is a rare disease characterized by humoral immunodeficiency, often causing sinopulmonary and gastrointestinal infections, and may cause enteropathy in some patients, which leads to severe malnutrition and electrolyte deficiencies. Although many autoimmune diseases are seen with increased frequency in CVID patients, primary hypoparathyroidism is extremely rare.

Case presentation. A 50-year-old man with CVID presented with diarrhea. The patient had complaints for 2 years and was cachectic. He had severe electrolyte and vitamin deficiencies that did not respond to oral treatment. The diarrhea causes such as celiac, inflammatory bowel diseases, and gastrointestinal infections were excluded and the endoscopy showed enteropathic changes in the duodenum and colon. Concomitant hypoparathyroidism was also detected in the patient with hypocalcemia despite adequate replacement.

Conclusion. Parenteral therapy should be considered in the management of CVID enteropathy cases that do not respond to oral replacement. Although very rare, hypoparathyroidism should be considered in the differential diagnosis of CVID patients with treatment-resistant hypocalcemia.
\end{abstract}

Key words: hypoparathyroidism, electrolyte deficiency, CVID, enteropathy, colitis.

\section{What is new/what is important}

1. Parenteral therapy should be considered in the management of CVID enteropathy cases that do not respond to oral replacement.

2. The incidence of many autoimmune diseases increases in CVID patients but hypoparathyroidism is extremely rare.

3. Although very rare, hypoparathyroidism should be considered in the differential diagnosis of CVID patients with treatment-resistant hypocalcemia.

\section{INTRODUCTION}

Common variable immunodeficiency (CVID) is the most common symptomatic primary immunodeficiency characterized by impaired B-cell differentiation with defective immunoglobulin production. Its prevalence ranges from 1:50,000 to $1: 200,000$ in the population and both sexes are affected equally $[1,2]$. The diagnosis of CVID is based on a low IgG level, together with IgA and/or IgM deficiencies and inadequate antibody response to vaccines. In addition, other causes of hypogammaglobulinemia should be excluded [3].
CVID usually occurs with recurrent sinopulmonary and gastrointestinal infections. The frequency of autoimmune, granulomatous and malignant diseases also increased [4]. Some CVID patients have bowel symptoms such as chronic diarrhea without any infectious cause and inflammatory enteropathy is detected in histopathological examinations. These findings have different characteristics from inflammatory bowel disease and celiac disease and are defined as CVID enteropathy $[2,5,6]$.

The most common autoimmune diseases in CVID patients are autoimmune thrombocytopenic purpura and autoimmune hemolytic anemia. 
Rheumatoid arthritis, autoimmune thyroiditis, pernicious anemia, Sjögren's syndrome, and vasculitis are also encountered $[1,7]$.

According to our knowledge, primary hypoparathyroidism in CVID patients was previously described only in one case [8].

\section{CASE PRESENTATION}

A 50-year-old male with a history of CVID for 6 years was admitted with complaints of fever, chills, and diarrhea (Table 1). The patient had diarrhea 3-4 times a day with the semi-solid character that did not contain blood. He also complained of numbness and tingling on fingertips, weakness, abdominal distention, and anal pain during defecation. On physical examination, he had abdominal tenderness but there was no guarding, rebound, and hepatosplenomegaly. The patient was cachectic. The Trousseau sign, which is a latent hypocalcemia finding that we noticed and controlled while measuring blood pressure, was positive.

Table 1

Immunoglobulin values at initial diagnosis

\begin{tabular}{|c|c|c|}
\hline Immunoglobulin & Values $(\mathrm{mg} / \mathrm{dL})$ & Normal range \\
\hline IgG & 235 & $554-1464$ \\
\hline IgG1 & 182 & $293-968$ \\
\hline IgG2 & 69.7 & $112-317$ \\
\hline IgG3 & 20.8 & $27-111$ \\
\hline IgA & $<27$ & $41-263$ \\
\hline IgM & $<18$ & $56-234$ \\
\hline
\end{tabular}

Laboratory analysis in application revealed total protein $5.3 \mathrm{~g} / \mathrm{dL}(6.4-8.3)$, albumin $3.7 \mathrm{~g} / \mathrm{dL}$ (3.5-5.2), globulin $1.6 \mathrm{~g} / \mathrm{dL}$ (2.5-3.5), urea $16 \mathrm{mg} / \mathrm{dL}$ (10-50), creatinine $0.66 \mathrm{mg} / \mathrm{dL}(0.7-1.3)$, potassium $3.2 \mathrm{mEq} / \mathrm{L}(3.5-5), 24$ hours urine potassium $13 \mathrm{mEq} / 24 \mathrm{~h}$, calcium $6.4 \mathrm{mg} / \mathrm{dL}$ (8.6-10.2), phosphorus $0.9 \mathrm{mg} / \mathrm{dL}$ (2.3-4.5), magnesium $0.44 \mathrm{mg} / \mathrm{dL}$ (1.5-2.6), parathyroid hormone (PTH) $17.84 \mathrm{ng} / \mathrm{L}$ (15-65), leukocyte $5.98 \times 10^{3} / \mu \mathrm{L}$ (4.5-11.0), eosinophil $0.08 \times$ $10^{3} / \mu \mathrm{L}(0-0.45)$, hemoglobin $9.1 \mathrm{~g} / \mathrm{dL}(13.1-17.2)$, MCV $106.8 \mathrm{fL}(81-101)$, platelet $104 \times 10^{3} / \mu \mathrm{L}$ (150-450), and C-reactive protein $2.7 \mathrm{mg} / \mathrm{L}(0-5)$. Thyroid hormones, ACTH and cortisol levels were normal. The patient had no history of atopic disease, food allergy or intolerance, thyroid or parathyroid gland surgery and radiation therapy to the neck. Since the patient has chronic hypocalcemia due to hypoparathyroidism, there were no acute and severe symptoms. He was seronegative for HBV, $\mathrm{HCV}$, and HIV. Fecal calprotectin was negative. Cryptosporidium was detected in the stool culture. Genetic predisposition tests for celiac disease revealed HLA-DQ8 positive, HLA-DQ2 negative. Serum tissue transglutaminase (tTG)-IgA and endomysial (EMA)-IgA antibody tests were negative. In the multiple biopsies of the post-bulbar duodenum, lesions such as crypt hyperplasia and villus atrophy supporting celiac disease had not detected and the patient's diarrhea had not improve despite the longterm strict gluten-free diet.

The patient's diarrhea had been continuing at varying intervals for the last 2 years. When he presented to the gastroenterology clinic 2 years ago with the same complaints, he had underwent endoscopy and colonoscopy (Fig. 1). Endoscopic biopsy revealed no plasma cells in the sample taken from the duodenum, and IgA was negative in the stomach. In the colonoscopy, polymorphic leukocyte infiltration, mild architectural irregularity, and eosinophil infiltration $(>50 / \mathrm{HPF})$ were observed in the superficial epithelium of the cecum. Eosinophil leukocytes and significant architectural irregularity were observed in the sample taken from the rectum. Plasma cells were not observed in the specimens. When applied to us, the patient refused to undergo endoscopy and colonoscopy again.

The patient's abdominal ultrasonography (USG) showed mild splenomegaly and gallbladder sludge. Abdominal computed tomography (CT) showed enterocolitis in the jejunum and distal colon. The 25 hydroxyvitamin D level was $19 \mathrm{ng} / \mathrm{dl}$ and bone densitometry revealed femoral ( $\mathrm{T}$ score: -2.45 ; $\mathrm{Z}$ score: -2.13 ) and lumbar ( $\mathrm{T}$ score: -3.75 ; $\mathrm{Z}$ score: -3.39 ) osteoporosis. 


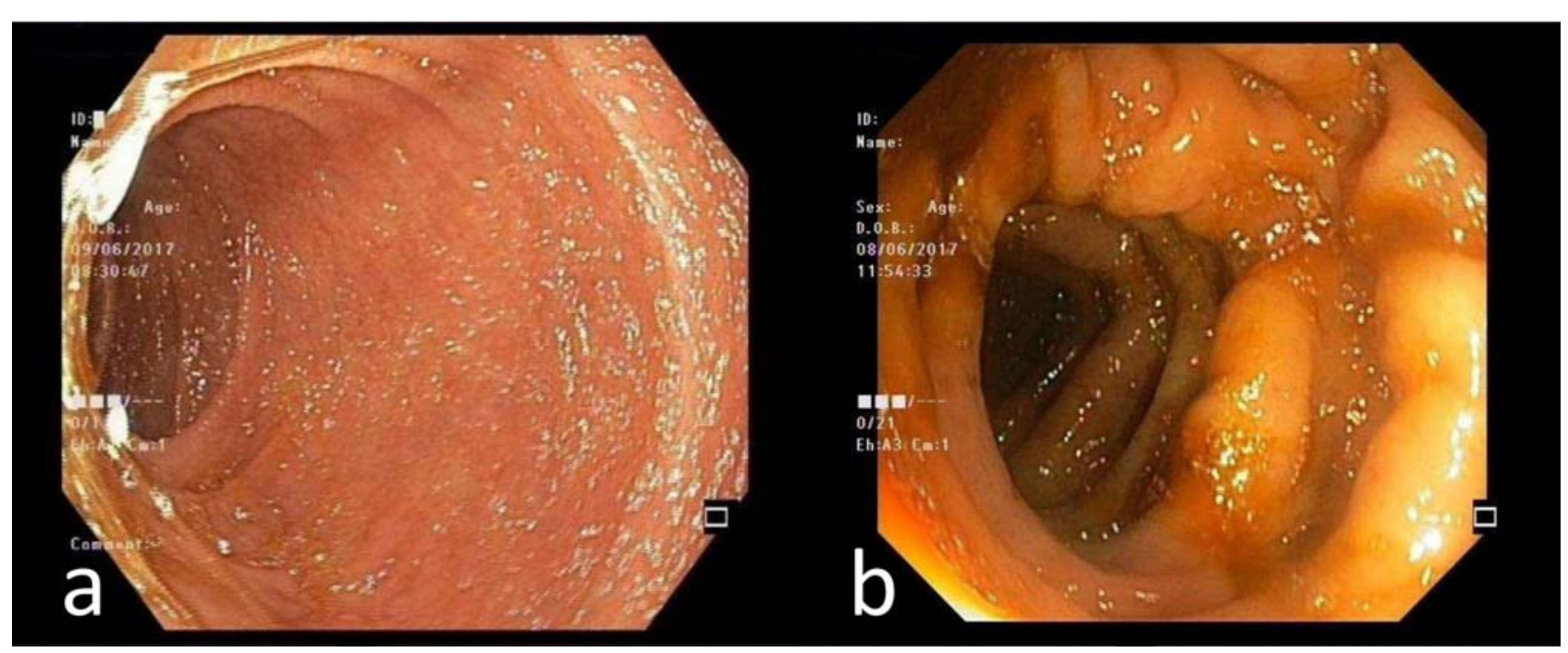

Figure 1. Endoscopy

a) Mucosal atrophy and papillary wiping in the second segment of the duodenum.

b) Normal colon mucosa appearance.

The patient had been receiving $30 \mathrm{~g}$ IVIG treatment every 3 weeks for the last two years and $50 \mathrm{~g}$ IVIG was applied at admission. Azithromycin $1,000 \mathrm{mg}$ per day was commenced for the Cryptosporidium infection. Oral calcium, magnesium, potassium, and phosphorus replacements were performed for electrolyte deficiencies. In addition, vitamin B12, folic acid, and vitamin D were added to the treatment due to low levels. There was no growth in the control stool culture on the $14^{\text {th }}$ day of azithromycin treatment, but diarrhea continued. Because of electrolyte deficiency persisted despite adequate replacement, intravenous treatment was applied. Although phosphorus and magnesium values were normal, calcium was $7.9 \mathrm{mg} / \mathrm{dL}$ and PTH was $11.6 \mathrm{ng} / \mathrm{L}$ after the replacement therapies.

\section{DISCUSSION}

Approximately $20-60 \%$ of CVID patients have gastrointestinal manifestations and in some patients, these may be initial findings. The most common gastrointestinal symptom is diarrhea $[4,9$, 10]. Although giardiasis is one of the most common infectious cause of diarrhea, Cryptosporidium parvum, Cytomegalovirus, Salmonella spp., and Campylobacter jejuni related diarrhea are also seen frequently [9]. Some CVID patients have chronic diarrhea without any infectious cause and these patients may have villous atrophy and crypt hyperplasia in intestinal histopathology similar to celiac disease. Because of immunoglobulin values were low, the measurement of tTG-IgA and EMA-IgA antibodies was not significant in the diagnosis of celiac. However, unlike celiac disease, CVID has a lack of plasma cells in intestinal biopsy and these patients do not respond to gluten-free diets, as in our patient $[6$, 11-13]. Although Cryptosporidium was not detected in the stool culture after azithromycin treatment in our patient, diarrhea and electrolyte deficiencies persisted. This suggesting that the primary cause of diarrhea was CVID-associated enteropathy, not the infection. As in our patient, in CVID enteropathy, eosinophil infiltration can be encountered in the intestinal epithelium similar to eosinophilic colitis (EC) [5]. The diagnosis of EC is challenging. Both clinical and histological features should be evaluated together. Eighty percent of patients have a coexistent atopic disease, while $62 \%$ experience specific food sensitivities. Peripheral eosinophil counts are elevated in $80 \%$ of patients [14]. Endoscopy in most cases shows generally normal mucosa, helping to distinguish EC from other forms of colitis. There are no guidelines to define an increased number of eosinophils in the colonic biopsies, because there are no certain limits for normality. Considering the non-allergic history, absence of peripheral eosinophilia and endoscopic findings in our patient, EC was not considered primarly.

Unlike X-linked agammaglobulinemia and IgA deficiency, gastrointestinal diseases are more common in CVID, and despite adequate immunoglobulin replacement, treatment success is not achieved. All these suggest that $\mathrm{T}$-cell dysfunction plays a role in the pathogenesis of the disease $[3,9,15,16]$. There are no definitive guidelines for the management of CVID enteropathy. Despite the use of corticosteroids and immunosuppressive agents besides immunoglobin 
replacement, their efficacy and tolerability are not well established. Recently, there are hopeful case reports with the use of TNF- $\alpha$ inhibitors in the literature, but further studies with a large number of patients are needed [3].

About $20-30 \%$ of CVID patients have autoimmune diseases. The most common autoimmune diseases are autoimmune thrombocytopenic purpura and autoimmune hemolytic anemia $[1,7,17]$. In our patient, Coombs test was negative and there were macrocytic anemia and thrombocytopenia due to vitamin B12 and folic acid deficiency. Primary hypoparathyroidism is very rare in CVID patients. In the presented case, hypocalcemia and hypoparathyroidism were found to be unresponsive to intensive parenteral $\mathrm{Ca}$ and $25-\mathrm{OH}$ vitamin $\mathrm{D}$ treatments and was replaced with 1,25 dihydroxy vitamin D. There was no response to peroral treatment due to intestinal malabsorption and the patient was followed up with parenteral treatment.
In our case, hypomagnesemia was also present, which may lead to impaired parathyroid hormone synthesis. However, continuing low PTH despite normal magnesium levels during follow-up suggests primary hypoparathyroidism. In further studies, our patient did not have any manifestations that supported autoimmune polyglandular syndrome type 1 such as mucocutaneous candidiasis, Addison's disease, alopecia, vitiligo, autoimmune thyroid diseases, and type 1 diabetes mellitus. As no available in our center, anti-calcium-sensing receptor (CaSR) antibodies were not studied.

Consequently, in CVID patients, appropriate parenteral replacement should be preferred in cases of electrolyte deficiency due to intestinal malabsorption. Although rare, hypoparathyroidism should be considered and evaluated in CVID patients with hypocalcemia unresponsive to 25-hydroxyvitamin D. Further studies that evaluate the PTH status in patients with CVID are needed.

Introducere. Imunodeficiența comună variabilă (CVID) este o boală rară a imunităţii cauzând infecţii sinopulmonare şi gastrointestinale cu enetropatie la unii pacienţi, ducând la malnutriţie severă şi deficite electrolitice. Hiperparatiroidismul este o asociere rară a CVID.

Prezentare de caz. Un pacient de sex masculin în vârstă de 50 de ani cu CVID se prezintă cu diaree. Pacientul spune că aceasta dura de 2 ani și la prezentare era cașectic. Avea un deficit electrolitic și o hipovitaminoză ce nu răspundeau la tratament. Au fost excluse alte cauze de sindrom diareic. Pacientului i-a fost descoperit și un hipoparatiroidism secundar cu hipocalcemie rebelă la tratament.

Concluzii. Terapia parenterală este de dorit la pacienții cu enetropatie asociată CVID. Deși rar, hipoparatiroidismul trebuie considerat ca diagnostic diferențial la pacienții cu CVID care prezintă hipocalcemie rezistentă la tratament.

Correspondence to: Rashad Ismayilov M.D. Ege University Faculty of Medicine, Postal code: 35100, Izmir, Turkey. Phone: +90507 033 1995, Fax: +90232 3437876

E-mail: ismayilov_r@hotmail.com

Acknowledgements: None.

Conflict of interest disclosure: The authors declare that there are no conflicts of interest.

\section{REFERENCES}

1. PARK MA., LI JT., HAGAN JB., MADDOX DE., ABRAHAM RS. Common variable immunodeficiency: a new look at an old disease. Expert Rev Clin Immunol. 2011; 7(2):129-131.

2. SALDANA DC., RUBIO IS. Immunodeficiencies and autoimmune diseases: Common variable immunodeficiency and crohnlike. Rev Esp Enfermedades Dig. 2016; 108(8):520-523.

3. ARIEIRA C., CASTRO FD., MOREIRA MJ., COTTER J. Common variable immunodeficiency-associated inflammatory enteropathy: The new era of biological therapy. GE Port J Gastroenterol. 2018; 25(6):322-326.

4. KHODADAD A., AGHAMOHAMMADI A., PARVANEH N., REZAEI N., MAHJOOB F., BASHASHATI M., et al. Gastrointestinal manifestations in patients with common variable immunodeficiency. Dig Dis Sci. 2007; 52(11):2977-2983. 
5. JORGENSEN SF., REIMS HM., FRYDENLUND D., HOLM K., PAULSEN V., MICHELSEN AE., et al. A Cross-Sectional Study of the Prevalence of Gastrointestinal Symptoms and Pathology in Patients with Common Variable Immunodeficiency. Am J Gastroenterol. 2016; 111(10):1467-1475.

6. PATEL J., KUMAR A., AGASTI A., CHOKSEY A., PHADKE A., SAWANT P. CVID enteropathy - A rare cause of chronic diarrhea in a child. Indian J Pediatr. 2012; 79(10):1374-1376.

7. ARKWRIGHT PD., ABINUN M., CANT AJ. Autoimmunity in human primary immunodeficiency diseases. Blood. 2002; 99(8): 2694-2703.

8. BASZKO-BLASZYK D., DWORACKI G., HORST-SIKORSKA WSJ. Primary hypoparathyroidism and hypergonadotropic hypogonadism in a male patient with common variable immunodeficiency. A case report. Pol Arch Med Wewn. 2005; 114(5): 1089-92.

9. AGARWAL S., MAYER L. Pathogenesis and treatment of gastrointestinal disease in antibody deficiency syndromes. J Allergy Clin Immunol. 2009; 124(4):658-664.

10. PIKKARAINEN S., MARTELIUS T., RISTIMAKI A., SIITONEN S., SEPPANEN MRJ., FARKKILA M. A High Prevalence of Gastrointestinal Manifestations in Common Variable Immunodeficiency. Am J Gastroenterol. 2019; 114(4):648-655.

11. CHOI SW., SEO KW., JI-SEON OH., LEE JS., HEE JEONG CHA. Successful treatment of enteropathy associated with common variable immunodeficiency. Korean J Intern Med. 2014; 29(2):256-258.

12. BIAGI F., BIANCHI PI., ZILLI A, MARCHESE A, LUINETTI O., LOUGARIS V., et al. The significance of duodenal mucosal atrophy in patients with common variable immunodeficiency: A clinical and histopathologic study. Am J Clin Pathol. 2012; 138(2): $185-189$.

13. VENHOFF N., EMMERICH F., NEAGU M., SALZER U., KOEHN C., DRIEVER S., et al. The role of HLA DQ2 and DQ8 in dissecting celiac-like disease in common variable immunodeficiency. J Clin Immunol. 2013; 33(5):909-916.

14. IMPELLIZZERIA G., MARASCOA G., EUSEBIA LH., SALFIB N., BAZZOLIA F., ZAGARI RM. Eosinophilic colitis: A clinical review. Digestive and Liver Disease. 2019; 51(6):769-773.

15. AGARWAL S., SMEREKA P., HARPAZ N., CUNNINGHAM-RUNDLES C., MAYER L. Characterization of immunologic defects in patients with common variable immunodeficiency (CVID) with intestinal disease. Inflamm Bowel Dis. 2011; 17(1):251-259.

16. ATALAIA-MARTINS C., BARBEIRO S., MARCOS P., COTRIM I., VASCONCELOS H. Common Variable Immunodeficiency with Several Gastrointestinal Manifestations. ACG Case Reports J. 2017; 4(1):e106.

17. PATUZZO G., BARBIERI A., TINAZZI E., VENERI D., ARGENTINO G., MORETTAF., et al. Autoimmunity and infection in common variable immunodeficiency (CVID). Autoimmun Rev. 2016; 15(9):877-882.

Received $3^{\text {rd }}$ August 2020 